Trees (1994) 8: $139-150$

\title{
The occurrence of flowering and fruiting on individual trees over 3 years and their effects on subsequent crown condition
}

\author{
John L. Innes* \\ Forestry Commission, Alice Holt Lodge, Wrecclesham, Farnham, Surrey GU4LH, UK
}

Received February 24/May 6, 1993

Summary. The level of fruiting in four forest trees species (Picea sitchensis, P. abies, Pinus sylvestris and Fagus sylvatica) was monitored in Great Britain over the period 1989-1991. In addition, assessments of crown transparency were available for many of the trees for 1987 and 1988. The monitoring period encompassed severe summer droughts in 1989 and 1990, with wetter conditions in 1991. Variations in the level of fruiting in spruce and beech (Fagus sylvatica L.) were seen, with a marked peak in 1990. No pattern was apparent in Scots pine (Pinus sylvestris L.). Coning, which was greater in trees with the least transparent crowns, had no discernible effect on the crown transparency of the conifers. Cupule production in beech was greatest in trees with the most transparent crowns, and trees with high numbers of cupules in 1990 tended to have greater crown dieback recorded in 1991.

Key words: Picea abies - Picea sitchensis - Pinus sylvestris - Fagus sylvatica - Fruit production

\section{Introduction}

The incidence of flowering in forest trees species is of considerable interest. Patterns of flowering in individual trees can yield a variety of information, ranging from carbon allocation to patterns in the environmental and genetic control of bud differentiation. Most studies looking at the incidence of flowering in the forest have been concerned with relatively small samples of trees, although the time series that is available in some studies is impressive (e.g. Koski and Tallquist 1987). Surveys of forest condition,

\footnotetext{
* Present address: Swiss Federal Institute for Forest, Snow and Landscape Research, CH-8903 Birmensdorf, Switzerland
}

now routinely undertaken throughout Europe and much of North America, provide an opportunity for the observation of a large number of individual trees through time.

There are many monitoring programmes which aim to determine annual and long-term variations in forest condition. Some co-ordination between these programmes has been achieved, but a number of problems still exist. These include the reference standards used, differences in sampling design and differences in how phenomena such as flowering are taken into account. Invariably, forest condition is assessed on the basis of only one or two indices: crown transparency and crown discoloration. Crown transparency is an extremely difficult index to interpret, as it reflects the combined effects of a number of simultaneous processes. In most cases, transparency is assessed by comparing the amount of foliage in the crown with what the observer considers should have been there. Although very subjective, intensive training of observers has resulted in this method obtaining high levels of reproducibility, both within and between observers (Innes 1993 b). Difficulties arise when the observers start taking into account factors that might influence the estimates of crown transparency. For example, in Finland, the effects of whipping, male flowering and infection by Peridermium are excluded from the transparency estimates (Jukola-Sulonen et al. 1990). This introduces a major element of uncertainty into the results and reduces the extent to which the results from different countries can be compared.

An important reason for foliage absence is the occurrence of flowering. In Scots pine, for example, male flower buds replace needle buds. The flowers are present during the early part of the summer but by the time of the annual assessments of crown condition in late summer, most of the flowers have been dropped. This results in the absence of needles on the older parts of shoots, giving the superficial appearance of needle loss. A similar pattern occurs in some broadleaved species with, for example, some of the leaf buds of beech being replaced by flower buds during years with flowering.

Flowering and subsequent seed production (if it occurs) may have important implications on the subsequent condi- 
tion of the tree. Early studies by Gross and Harden (1968), Kessler (1969) and Gross (1972) found that excessive seed production could be associated with the development of twig and branch dieback in subsequent years. In this context, dieback is different from transparency, the former involving the death of shoots and the latter including all causes of increased light penetration through the crown. However, it is not clear whether the relationship between dieback and fruit production is causal or whether the factors that trigger the flowering and seed production also trigger the dieback. As there may be a substantial level of synchroneity of flowering and seed production within a species (Zasada et al. 1992), an association between seed production and crown deterioration might be reflected in annual figures of crown condition. Consequently, studies of seed production form an important part of assessments of forest condition.

In energetic terms, trees devoting a substantial amount of resources to seed production might have fewer resources available for other physiological processes (Kozlowski and Keller 1966; Nielsen 1977). The seed crop may act as a major sink for photosynthate and nutrients (e.g. Nemec 1956; Fielding 1960; Ching and Ching 1962; Dickman and Kozlowski 1969). This is confirmed by increment studies, with a relationship between flowering, seed production and radial increment having been demonstrated (e.g. Eklund 1954, 1957; Morris 1951; Eis et al. 1965), although this is not universal (Chalupka et al. 1976). Many dendroecological studies are based on the establishment of relationships between climate and radial growth. If climate also affects flowering and seed production (e.g. Eklund 1954, 1957; Lindgren et al. 1977), then the relationship between climate and radial growth may be affected by the presence or absence of flowering and/or fruiting.

Seed production has also been associated with reduced crown expansion (Caesar and Macdonald 1984). If leaf buds are replaced in a particular year by flower buds, then a year with high levels of flowering may also be accompanied by reduced levels of assimilate production. This would reduce the resources available for recovery of the trees (Enescu 1987). If this concept is valid, then trees with high levels of flowering in one year might be expected to show signs of poor crown condition the following year. This could take the form of increased crown transparency or could be more serious, appearing as shoot and branch dieback.

Excessive production of seed is often an indicator of imminent mortality (Owens and Blake 1985) and the monitoring of seed crops may be provide a useful indication of the presence of severe stresses. Late frosts have been found to increase the cone crops of larch the following year (Wachter 1959, 1962) and similar effects have been seen in Douglas fir (Ebell 1971). Analyses of the seed in such situations indicates that a high proportion is poorly developed suggesting a failure of the normal regulatory systems controlling flowering and fruit production.

The monitoring of flowering and seed production in forests may also be useful in the context of other studies. The control of sex expression in conifers is believed to be under hormonal control, involving the interaction between gibberellins and auxin (Pharis and King 1985), although the relationship is less clear with the Pinaceae (Krulikowska et al. 1978; Ross and Pharis 1987; Ross 1990). However, environmental factors are also involved, and the detailed monitoring of the incidence of male and female flowering and the careful scrutiny of meteorological records for particular sites could help the identification of critical environmental conditions and critical periods for differentiation. In addition, given that the transfer of grafts of Norway spruce southwards has been shown to increase the propensity of Norway spruce to flower (Melchior 1987), the possibility of a climatic change towards warmer temperatures may have important implications for the occurrence of flowering.

Flowering can result in subtle structural alterations to the crown in many species (e.g. Lüscher 1989a, 1989 b, 1990; Lüscher and Sieber 1988). However, the significance and persistence of these effects is rather uncertain. In subalpine fir [Abies lasiocarpa (Hook.) Nutt.], for example, potential cone-buds may become latent and then develop into shoots that are much less vigorous than shoots derived from vegetative buds (Owens and Singh 1982). In Douglas fir, Owens (1987) found that the shoots producing the greatest numbers of cone buds were those that had previously shown the greatest retardation of apical development. Owens and Molder (1976) argued that in Sitka spruce, cones are terminal in years when coning is sparse but that they are both terminal and axillary in years with abundant coning. In the Pinaceae in general, seed cones tend to be located on vigorous lower order shoots and pollen cones on less vigorous higher order shoots (Wareing 1958; Debazac 1965; Baradat 1967).

Another complicating factor is the purported relationship between the occurrence of flowering and stress. Excessive flowering and seed production in a tree may be a direct response to severe stress, and limited amounts of moisture and other forms of stress are frequently applied to seed orchards to promote flowering (e.g. Jackson and Sweet 1972; Puritch 1972; Philipson 1987), although with variable results. Girdling has been widely applied (Ebell 1971; Philipson 1985). However, the effects of girdling are not always readily apparent; Bonnet-Masimbert (1987) found no effect of girdling on the incidence of flowering in Norway spruce, although girdling in combination with gibberellin treatment reduced male flowering. In Sitka spruce, the enhancement of flowering after girdling was only evident in cases where flowering would have been weak without treatment (Philipson 1987). Root pruning has also been used to enhance flowering (Ross et al. 1985; Webber et al. 1985), as has root flooding (Bonnet-Masimbert 1982). The relationship with stress is not applicable to nutrition: fertilisation of trees results in increased flowering and cone or cupule production (Le Tacon et al. 1977; Mikola 1987; Wesoly et al. 1987). If this is the case, then it might be expected that trees showing previous signs of stress would show greater levels of fruiting in years of fruit production.

In this paper, data from the British monitoring programme are used to assess whether there are any relationships between the incidence of flowering, seed production and the past, present or future crown condition of individual trees. 


\section{Past studies}

A substantial number of experimental studies have indicated the importance of both drought and temperature in the promotion of flowering in Sitka spruce (e.g. Tompsett and Fletcher 1977, 1979; Philipson 1983) and Norway spruce (Olsen 1978; Chalupka et al. 1982; Melchior 1987). In Scandinavia, the cone yield of Norway spruce [Picea abies (L.) Karst.] is at least partly dependent on temperature (Tirén 1935; Eklund 1954, 1957; Lindgren et al. 1977). Coning was related to the air temperature in the second half of June and the first half of July during the year of bud formation (i.e. the year preceding the coning). Moisture also appears to be important, with several studies suggesting that dry summers may increase cone production (e.g. La Bastide and Van Vredenburch 1970). As with beech described below, long time series indicate that the relationship between warm, dry summers and the occurrence of coning is unstable, with other factors clearly playing a part (Sarvas 1957).

No similar information appears to be available for Sitka spruce [Picea sitchensis (Bong). Carr.] and, given its very different natural habitat, the same response would not necessarily be expected. There is some evidence that Sitka spruce differs from other species in the timing of bud differentiation (Moir and Fox 1975), but this study was based on morphological characteristics which, by definition, must occur at some time after the differentiation. Owens and Molder (1980) state that in its natural habitat, Sitka spruce is a prolific seed producer with good cone crops occurring every 3-4 years (Fowells 1965). Cones are primarily produced in the upper part of the crown (Owens and Molder 1976). There is some evidence that the phenology of cone development differs between Great Britain and British Columbia (Moir and Fox 1975), although interpretation is complicated by the effects of provenance (Burley 1966a, b).

In other species, clear relationships exist between cone abortion and external stress factors. In Douglas fir [Pseudotsuga menziesii (Mirb.) Franco], cone abortion at and shortly after pollination has been attributed to high moisture, low temperatures and the activities of microorganisms (Owens et al. 1991).

A considerable amount of information is available on the flowering of Scots pine. The formation of flower bud primordia occurs between May and July, depending on the latitude (Stanley 1958). The abundance of male flowering shows considerable genetic variation (Sarvas 1962; Jonsson et al. 1976; Chung 1981). Flowering fluctuates from year to year, although the relative extent of flowering in individual trees remains fairly consistent (Jonsson et al. 1976). Good cone production may be associated with high summer temperatures during the year of reproductive bud differentiation (Hagem 1917; Fober 1976) and also in the year prior to reproductive bud differentiation. Similar results have been obtained for ponderosa pine (Pinus ponderosa Dougl.; Maguire 1956; Daubenmire 1960). A relationship exists between the extent of male flowering and the extent of female flowering and coning on individual trees. Trees with few male flowers tend to have few female flowers. Conversely, trees with abundant male

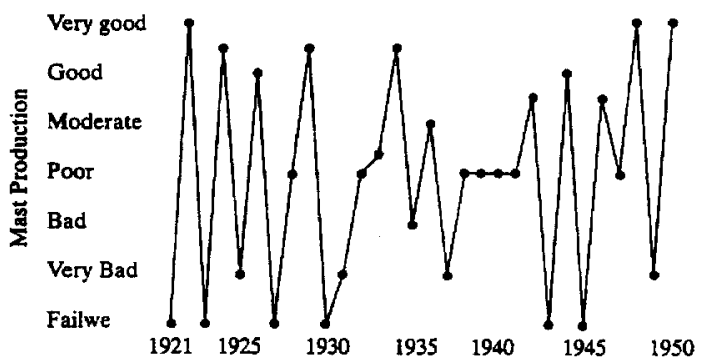

Fig. 1. Variation in the mast production of beech in southern England between 1920 and 1950. Drawn from data presented by Matthews (1955)

flowers only produce moderate numbers of female flowers (Nikkanen and Velling 1987). Nikkanen and Velling (1987) also identified a relationship between flowering abundance and crown quality, with the most abundant flowering occurring on clones with wide crowns and thick and abundant branches (i.e. poor-quality crowns). The extent of female flowering responds to the application of fertilisers, although the responses are very variable (see reviews by Puritch 1972 and Lee 1979). Male flowering appears to respond less to fertiliser applications (Wesoly et al. 1987). Long-term studies of seed production in Scots pine (Koski and Tallquist 1987) suggest that years of heavy seed production rarely occur consecutively.

Lindquist (1931) examined the incidence of flowering and mast production in Scandinavian beech forests. He concluded that flowering was a periodic process that was at least partly determined by environmental conditions. In addition, he noted that abundant flowering did not occur every year, regardless of the preceding environmental conditions. Matthews (1955) summarised information on the known flowering patterns of beech in the south of England for the period 1921 to 1950 . A marked pattern was found, with years with high levels of fruiting invariably being followed by years of low levels of fruiting (Fig. 1). Years with low levels of fruiting were not necessarily followed by years with high levels of fruiting. Hilton and Packham (1986) have suggested from a 5-year study of mast production that heavier fruiting tends to occur every other year, although in subsequent years, the pattern seen between 1980 and 1984 has broken down (Packham et al. 1992), indicating the importance of long time series in phenological observations. The pattern identified by Matthews (1955) is now well-established in the literature (Owens and Blake 1985). The indices used by Matthews (1955) were based on subjective observations rather than on any systematic survey. However, a number of interesting observations were noted by Matthews. For instance, it was apparent that mast production by isolated trees and trees located on forest edges was much greater than on trees located in the forest interior. Summer temperature had a marked effect on the occurrence of flowering in the subsequent year, but the relationship was complicated by spring frosts, which could result in the loss of flowers in any given year. The effects of such frosts are particularly noticeable in broadleaves (Watt 1925; Oppermann and Bornesbusch 1926; Brown 1953; Matthews 1955), with temperatures of $-1^{\circ} \mathrm{C}$ being sufficient to kill the male flowers of beech (Oppermann and Bornesbusch 1926). 
Numerous studies have documented heavy flowering and fruit production in years following hot dry summers (e.g., Linnaeus 1751; Watt 1925; Busgen et al. 1929; Lindquist 1931; Baldwin 1942; Matthews 1955; Holmsgaard and Olsen 1960). This relationship was identified (for beech) as early as the summer of 1748 , suggesting that it occurs regardless of more recent stresses associated with hot, dry summers (e.g. high ozone concentrations).

There have been fewer studies linking crown condition to fruiting. Flückiger et al. (1989) noted that the production of cupules on beech trees with very transparent crowns was higher than on trees with low levels of transparency. This would be expected as flower buds replace leaves in beech. Stütz et al. (1987) looked at the incidence of coning in Norway spruce finding no relationships between the production of viable seed and crown transparency. However, a later study by Löffler (1988) suggested that the incidence of coning on trees with transparency values in excess of $60 \%$ was less than in trees with lower transparency values. Innes (1992) found a strong relationship between the presence of cupules in beech and the presence of unusually small leaves. There was also an apparent pattern for both the number of cupules and the incidence of small leaves to be higher in trees with more transparent crowns. If a relationship does exist, the cause-effect pattern is unclear. A number of studies have demonstrated a positive response of flowering to light intensity (e.g. Sarvas 1962; Simpson and Powell 1981), and the relationship between transparency and flowering may be related to this. Alternatively, both crown transparency and higher levels of flowering may be a response to stress.

\section{Materials and methods}

Data were collected as part of the routine monitoring programme undertaken each year during July and August in British forests. The data used in this study were collected in 1989, 1990 and 1991, with 1990 being noted as a year of marked seed production in a wide range of species. This was probably related to the very dry weather conditions recorded throughout much of the summer of 1989 (Innes et al. 1989).

Data were collected from 24 trees per plot, with the number of plots per species varying among the four species examined (Sitka spruce, Norway spruce, Scots pine and European beech). Data were collected for oak (Quercus spp.), but the information was considered too unreliable to use as the observation of acorns was strongly biased towards the end of the field season. Estimates of crown transparency, dieback and fruiting were made from the ground by trained observers using binoculars. Transparency, defined as the amount of light passing through the crown in comparison with a fully-foliaged tree, was assessed in $5 \%$ classes relative to standard photographs (Innes 1990) and all other assessments followed the standard operating procedures used in the British forest monitoring programme (Innes 1990). Higher scores for transparency indicate increased levels of transparency (i. e. lower quantities of foliage in the crown), with no allowance being made for the cause of the reduced foliage quantity. Crown dieback in beech was assessed using the classification proposed by Westman (1989), with the nature, location and extent of dieback being recorded. The extent of flowering in Scots pine was estimated in four categories depending on the proportion of branches affected $(0-10 \%, 11-25 \%, 26-60 \%,>60 \%)$ and the position of the branches in the crown (upper or lower half). Fruiting in all trees was assessed on a 4-point scale: none, rare, common and abundant, with the scores being for the number of cones (conifers) or cupules (beech) rather than the numbers of viable (or non-viable) seeds produced. A sample of
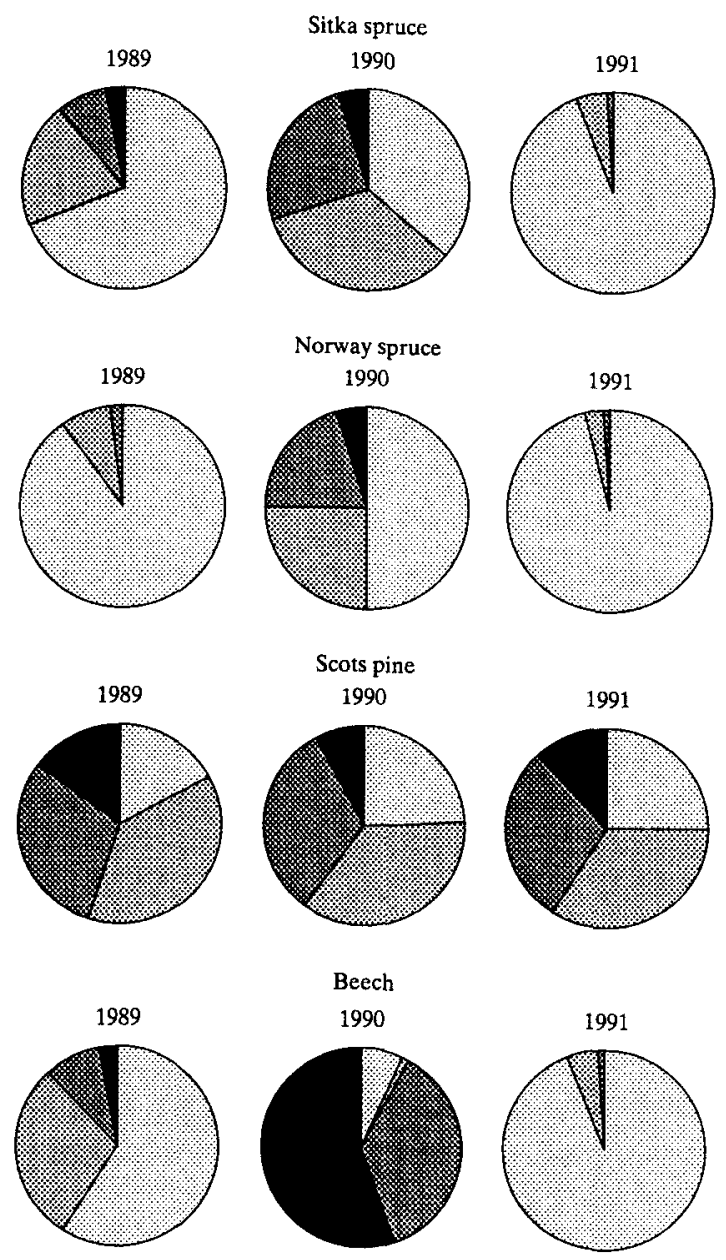

Fig. 2. Percentages of trees with a given level of fruiting. For spruce, only fresh cones were included. For Scots pine, only unopened 2nd-year

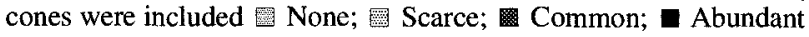

plots were visited by an independent observer to check consistency between different field crews.

The statistical analysis of such material is difficult because of the large sample numbers (Köhl 1989, 1990). These mean that very low correlation coefficients are nevertheless significant, as illustrated in Table 1, where the $P<0.01$ significance level was for $r=0.075$. Several methods were used to overcome this problem, particularly the conversion of the data to proportions. In addition, for the categorical data, non-parametric tests, mainly the Kolmogorov-Smirnov test were used. The specific test used for each correlation is indicated in the text. Because of the problems of determining significance, graphical methods of presenting the data have also been used.

\section{Results}

The scores for fruiting for each species during the period 1989-1991 are given in Fig. 2. The marked increase in coning of Sitka spruce and Norway spruce is evident in 1990 , as is the large numbers of cupules in beech. Conversely, the incidence of coning in Scots pine remained remarkably constant over the three-year period. Sitka spruce had higher levels of coning than Norway spruce 
Table 1. Comparison between flowering in top (upper table) and lower (lower table) parts of the crown in 1989 and 1991

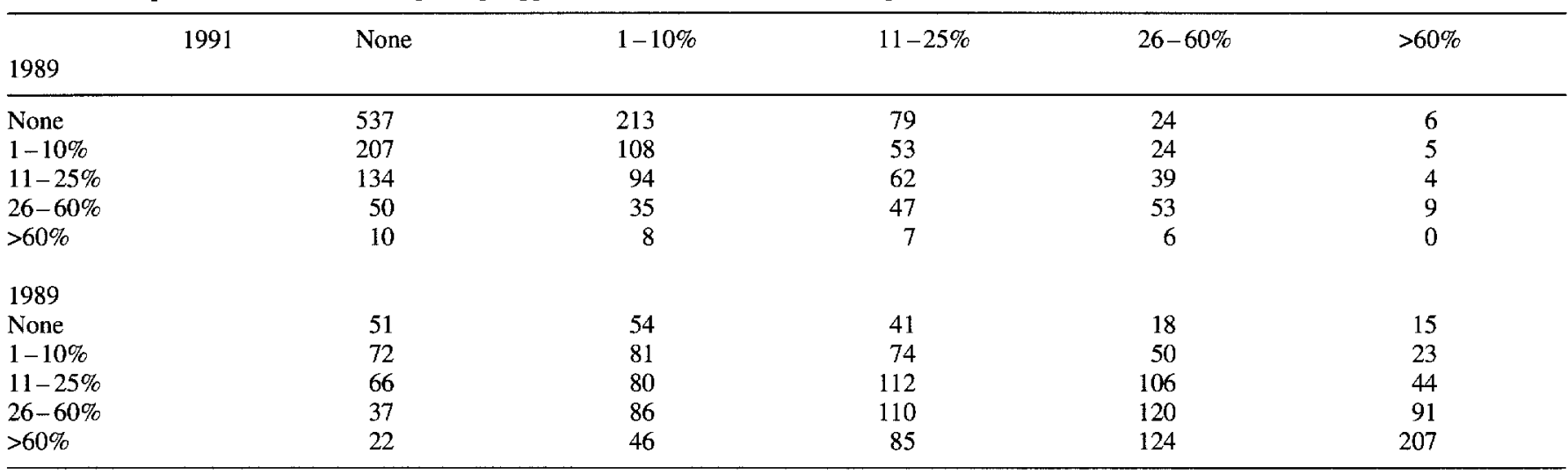

Table 2. Correlations among flowering, coning and crown transparency of Scots pine

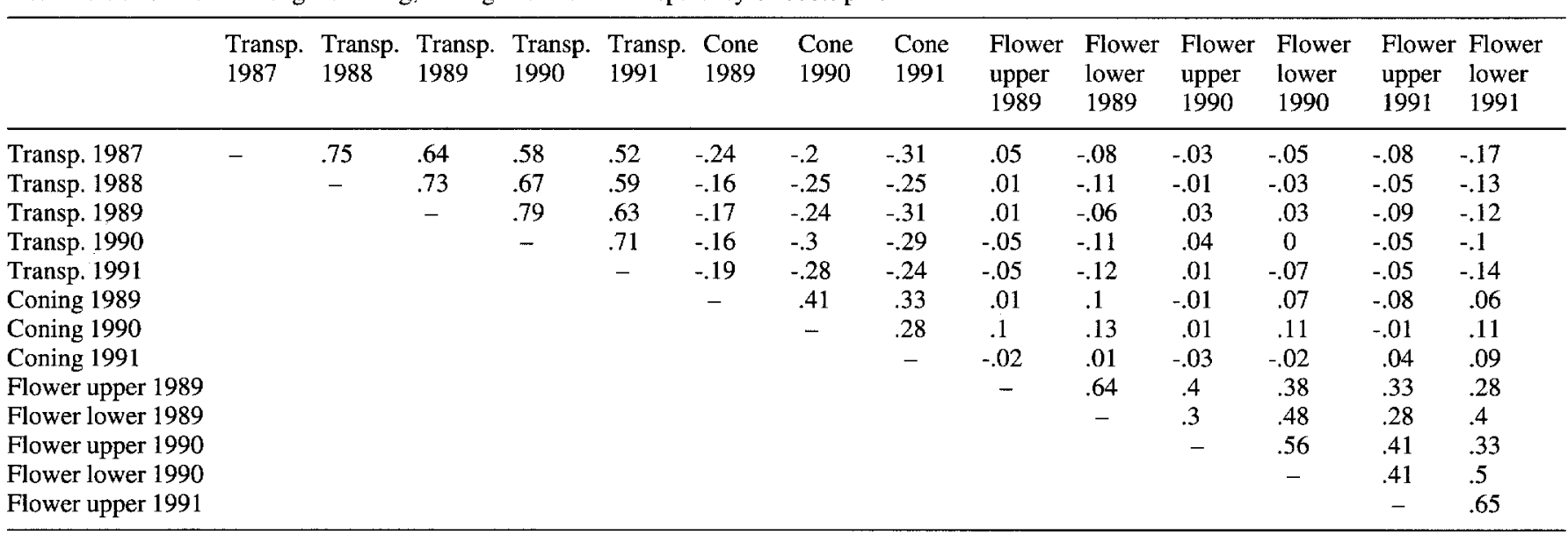

Transp., crown transparency

Cone, amount of coning

[significantly $(P<0.001)$ higher in 1989 and 1990, but insignificant in 1991].

\section{Pattern of flowering and coning in individual trees}

Several studies (e.g. Matthews 1955; Harper 1977; Owens and Blake 1985) have suggested that a good year for fruit production is not followed by another, and the series shown in Fig. 1 appears to confirm this. However, the interpretation of records for particular regions is complicated by the aggregation of all trees, resulting in differences in the behaviour of individual trees being lost. It is possible that individual trees may fruit asynchronously, resulting in considerable "noise" in the data. Although only 3 years of records are available, the data collected in this study can be related to individual trees, enabling this hypothesis to be examined.

With Sitka spruce, any trend is complicated by the large amount of coning seen in 1990 and the very low levels of coning in 1991 . Most $(91 \%)$ trees with coning present in 1989 also had coning present in 1990, although an absence of coning in 1989 was a poor indicator of the likelihood of coning in 1990 . Only $48 \%$ of the trees without coning in 1989 were also without coning in 1990. A higher propor-
Flower upper, amount of flowering in the upper half of the crown Flower lower, amount of flowering in the lower half of the crown

tion $(9.3 \%)$ of trees with coning in 1989 had cones present in 1991 than the proportion of trees without coning in 1989 (3\%) (Fig. 3). A similar pattern was evident for Norway spruce, although the propensity for trees with cones in 1989 also to have them in 1991 was less obvious $(7.8 \%$ vs $2.6 \%$ ).

The numbers of cupules on beech showed a similar year-to-year pattern to the abundance of coning in the two spruce species (Fig. 3). However, the virtual absence of fresh cupules in 1991 means that comparisons can only be made between 1989 and 1990 . Most (98\%) trees with cupules in 1989 had cupules in 1990 and, in addition, 98\% of the trees with common to abundant cupules in 1989 had common to abundant scores for cupules in 1990 , as reported by Innes (1992). Many trees had cupules present in the crowns in 1991, but close observation revealed that they were all old. In many cases, the old cupules were not dropped until autumn 1992. The retention of the old cupules represents a potential problem, as observers might confuse them with new ones. However, all observers were briefed on this possibility, and the retention of old cupules is not believed to have been a problem in the assessments.

Considerable changes in the amount of flowering in Scots pine were evident from year to year, with the presence of a given amount of flowering in 1989 being a poor 

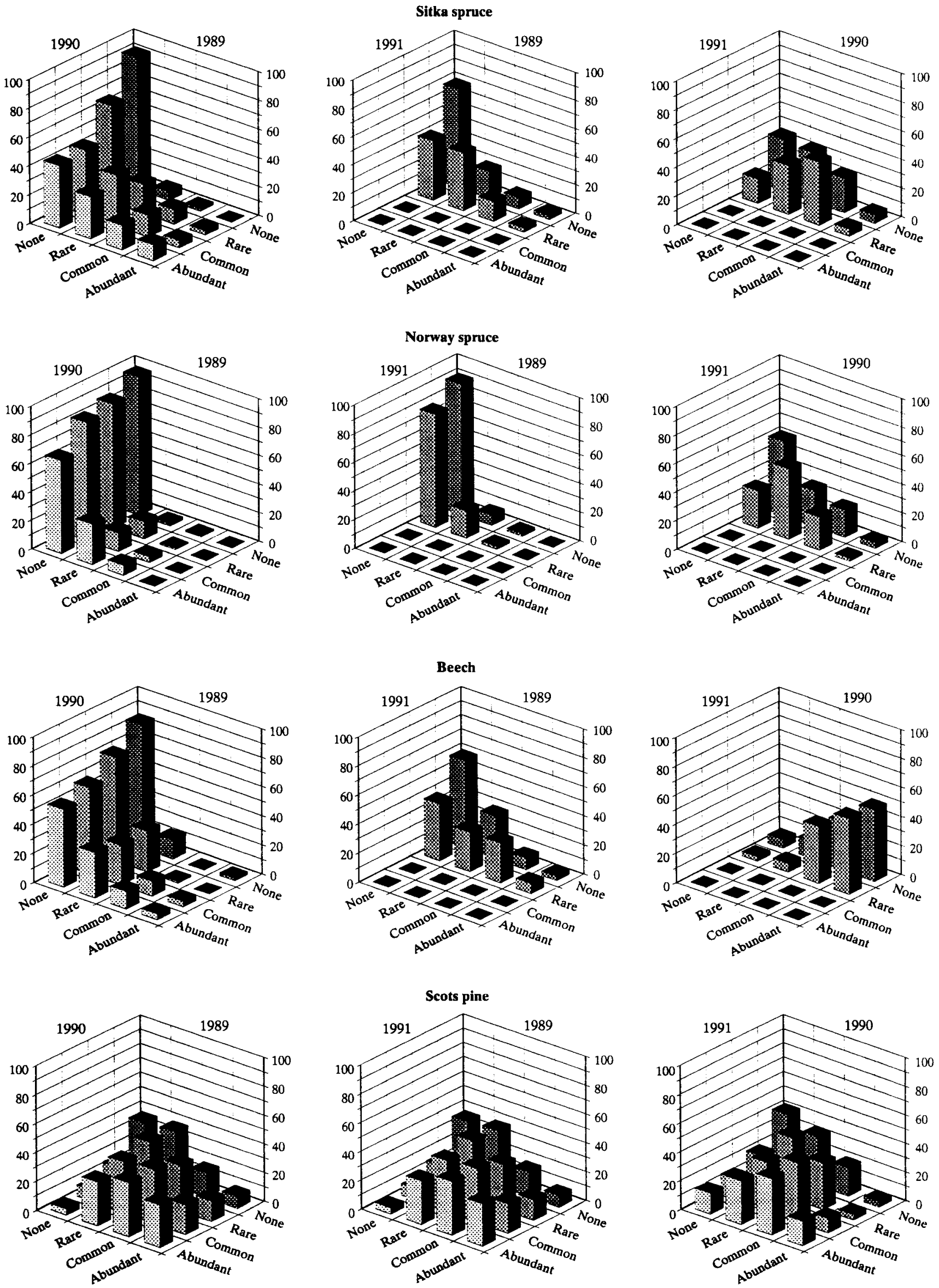
Table 3. Relationship between the abundance of flowering in the upper and lower parts of the crowns of Scots pine in $1989-1991$

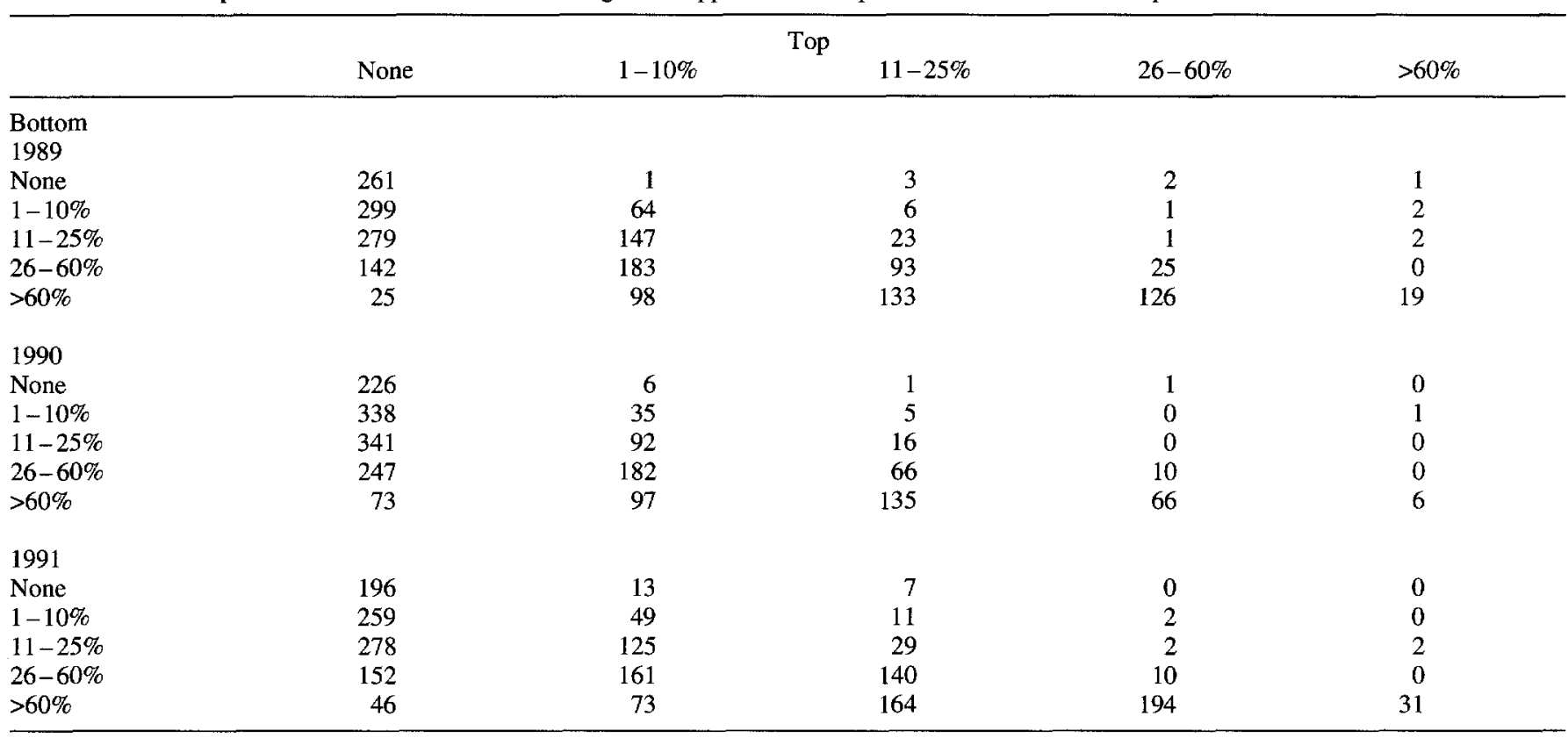

predictor of flowering in 1991 (Table 1). However, the levels of flowering in the three years were significantly correlated (Table 2), confirming that the relative amount of flowering on trees remains consistent. Within any year, the amount of flowering in the upper and lower portions of the crown were highly correlated, as reported previously (Innes and Boswell 1991), although flowering was nearly always higher in the lower crown than in the upper half (Table 3). This contrasts with many observations that flowering in Scots pine (and other species) is positively related to light intensity (Sarvas 1962; Smith and Stanley 1969).

The data for coning in Scots pine are rather more difficult to interpret than the data for the two spruce species. As with the flowering, a considerable amount of year-to-year variation was seen on individual trees. However, there was not the marked peak in fruiting in 1990 that was seen on spruce and beech. A significant trend was present, with trees with coning in one year also tending to have coning in the two other years. This trend was remarkably consistent.

\section{Relationship between fruiting and crown transparency}

There are a number of possible relationships that might exist between fruiting and transparency. The level of crown transparency may be related in the amount of fruit-

Fig. 3. Changes in the amount of fruiting on individual trees between 1989 and 1991. Proportions indicate the percentages of trees in the earlier year that were in a given category in the more recent year. For example, in the top middle figure, $42 \%$ and $41 \%$ of the trees where coning was classed as rare in 1991 had no or rare coning, respectively, in 1989. In 1991 , there were no trees where coning was scored as common or abundant ing in the same year. This could occur both as a genuine function and as an artefact of the observation techniques, as trees with very high levels of fruiting can be appear to have denser crowns than trees with low levels of fruiting. Heavy fruiting may cause an increase in transparency the following year due to changes in the allocation of assimilates. Another possibility is that trees with transparent crowns may be more prone to fruiting. These possibilities have been examined in relation to beech (Fig. 4). In 1990, there was a suggestion that trees with more than $30 \%$ transparency in 1989 produced fewer cupules in 1990, but this trend was not statistically significant (Kolmogorov-Smirnov test, $P=0.01$ ). There was no indication of any relationships between the transparency levels in 1988 and the amount of fruiting in 1990.

A clear relationship between the numbers of beech cupules and the levels of transparency was apparent in 1990. Differences in the crown transparency distributions among the different fruiting classes were also seen in 1989 , but the differences did not follow the clear pattern seen in 1990. Cupules were more abundant on trees with more transparent crowns in both 1989 and 1990.

The numbers of cupules on beech trees in 1989 affected the crown transparency in 1990, but the relationship was not clear. For example, $71 \%$ of the trees with common to abundant cupules had $>15 \%$ crown transparency. In contrast, $75 \%$ of the trees with no or rare cupules had $<15 \%$ crown transparency. A noticeable trend was apparent when the 1990 fruiting levels were compared with crown transparency in 1991, with trees with high levels of fruiting in 1990 having significantly higher levels of transparency in 1991. However, it is important to note that these do not necessarily represent causal relationships.

A very different pattern is evident with Sitka spruce and Scots pine. Here, coning tended to be greater on trees with denser crowns, very transparent crowns having low levels of coning (Fig. 5). This pattern was also apparent with 

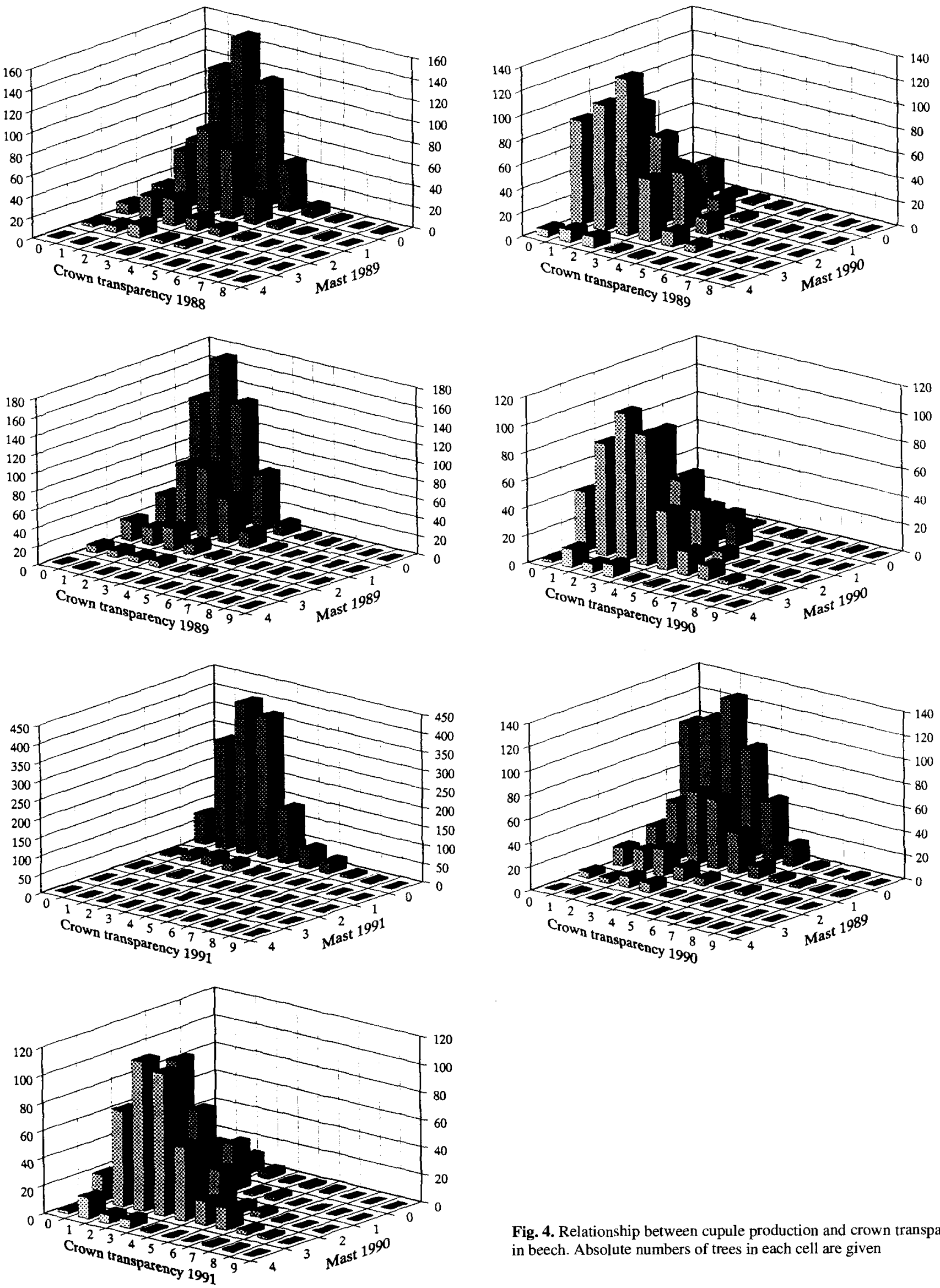

Fig. 4. Relationship between cupule production and crown transparency in beech. Absolute numbers of trees in each cell are given 


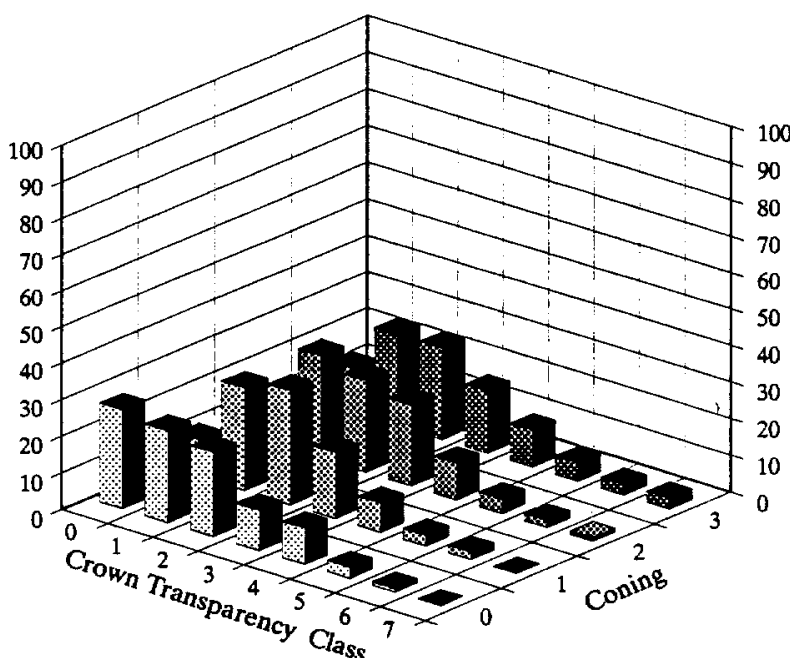

Fig. 5. Relationship between crown transparency and coning in Sitka spruce, 1990. Proportions indicate the percentages of trees in each coning category that had a given crown transparency class. Transparency classes: $0=0-10 \%, l=11-20 \%, 2=21-30 \% \ldots 7=71-80 \%$

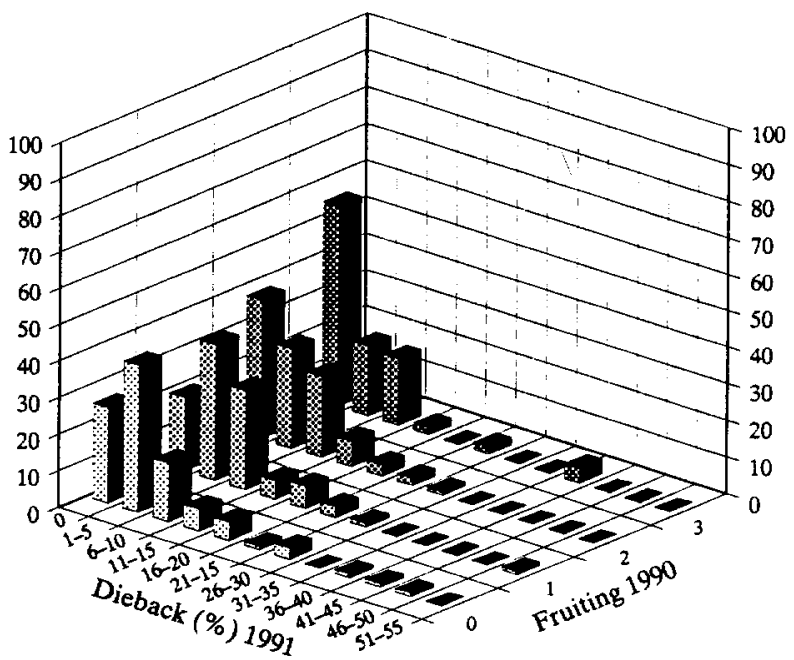

Fig. 6. Relationship between the extent of cupule production in 1990 and crown dieback in 1991 in beech. Proportions indicate the percentages of trees in each fruiting category in 1990 with a given level of dieback in 1991

Norway spruce, but the differences were not significant. There was no evidence that the amount of coning in either Sitka or Norway spruce in 1990 affected the crown transparency score the following year.

\section{Flowering, coning and crown transparency in Scots pine}

The presence of male flowers on sections of shoots precludes the presence of needles. At the time of the annual assessments of crown condition (July-August), the flowers have usually fallen, leaving bare areas of shoot. This has been recognised as a potential problem in the assessment of the transparency of crowns. Some countries have countered this by attempting to exclude the effects of flowering from the transparency estimates. In Britain, past flowering is seen as one of the factors affecting transparency, and the effects are therefore included in the overall transparency assessment.

The relationships between crown transparency, flowering and cone production in Scots pine are shown in Table 2. A number of trends are apparent in these data. The scores for crown transparency in one year are strongly correlated with the scores for crown transparency in the following year, the effect diminishing with time (as might be expected). A similar, but less marked, pattern is evident for coning. A negative relationship exists between transparency and the amount of coning, with coning being greater in denser crowns. Correlations between male flowering and coning were either very weak $(0.07<r<0.15)$ or non-significant. Similarly, only weak $(r<0.17)$ relationships were identified between crown transparency and the amount of male flowering.

\section{Cupule production in beech and crown dieback}

One of the basic assertions of Gross (1972) and Gross and Harden (1968) was that excessive coning was accompanied by dieback in successive years. There was some indication of this in the British data for beech. The severity and extent of crown dieback in 1989 was correlated with the numbers of cupules that year, although the correlation coefficients (Spearman Rank $R$ ) were low $(<0.2)$. No such relationship existed in 1990 or 1991 . The numbers of cupules in 1990 were not correlated with the amount or severity of crown dieback in 1991.

Examination of the data reveals that the situation is more complex than suggested by the correlations (Fig. 6). The lowest levels of dieback in 1991 were associated with those trees that had the lowest numbers of cupules in 1990 , with $43 \%$ of the trees with no or rare cupules having $1 \%$ or less dieback. Trees with medium to high numbers of cupules in 1990 had significantly $(P=0.01)$ more dieback in 1991 than trees that had not produced cupules. However, the extent of dieback in 1991 in trees with low numbers of cupules in 1990 did not differ significantly from trees with no or medium to high numbers of cupules in 1990 .

\section{Discussion}

The substantial increase in the amount of coning seen on Sitka and Norway spruce and the numbers of cupules on beech in 1990 has been attributed to the dry, warm summer of 1989 (Innes and Boswell 1991; Innes 1992). Although the summer of 1990 was also dry and warm, fruiting was either rare or absent in many trees. This confirms that the presence of excessive fruiting in one year inhibits high levels of fruiting the following year, even when environmental conditions are suitable for the development of seed production. This trend may be the result of anatomical, morphological or physiological processes (or a combination). Seed production consumes energy and the production of heavy seed crops in successive years may be impossible for trees (Owens and Blake 1985). The production 
of seed in successive years is likely to be further affected by the reduced assimilate production in the year of fruiting caused by the replacement of foliage with seeds. This remains speculative and needs to be tested through experimental research and further field observations. In particular, the nature and importance of assimilate reserves requires attention.

A marked difference was seen between beech and the three coniferous species in the relationship between crown transparency and fruiting. In the conifers, coning was greater on trees with less transparent crowns. Conversely, cupule production in beech was greatest in those trees with the most transparent crowns. The reason for this difference is unknown. One possibility is that there are fundamental differences in the energy allocation of the different species when under climatic stress. This remains to be tested experimentally but, if true, it holds considerable implications for the evaluation of the potential response of forests to climatic change.

One of the principal aims of this study was determine whether fruiting had an adverse effect on crown condition, as suggested by Gross (1972) and Gross and Harden (1968). There was limited evidence that beech trees that produced cupules in 1990 had higher levels of crown dieback in 1991, but a causal relationship cannot be inferred from this relationship. There was no evidence of a similar relationship among the three coniferous species.

\section{Conclusions}

Long-term monitoring of forest condition has the potential of producing much useful information on the basic physiology of forest trees. As monitoring programmes become more detailed in their assessments of individual trees, the quality of information being gathered will increase.

Most national programmes are based on the assessment of crown transparency alone. The value of this information is very limited, primarily because of the complex nature of the phenomenon. As demonstrated here and in Innes (1993 a), collection of additional information can add substantially to the value of the monitoring. Adequate quality control is also necessary. Through such additional measures, it is possible to build up a better picture of the factors affecting the crown condition of forests.

In this study, the fruiting behaviour of beech and three coniferous species in relation to their crown transparency was very different. In beech, fruiting was greatest on trees with transparent crowns, and dieback was more prevalent in trees that had fruited heavily the previous year than in those that had not. In marked contrast, coning in Sitka and Norway spruce and Scots pine was greatest in trees with dense crowns and no effect of the coning was noted on crown transparency the following year.

Acknowledgements. Thanks are due to the foresters from the Forestry Commission's Forest Surveys Branch who made the observations, often under extremely arduous conditions. I am grateful to Markus Sieber, Rainer Matyssek and two anonymous referees for helpful comments on an earlier version of this manuscript.

\section{References}

Baldwin HI (1942) Forest tree seed. Chronica Botanica Co., Waltham, Mass.

Baradat P (1967) Etudes preliminaires sur la fructification du Douglas. Rev For Fr (Nancy) 11: 698-713

Bonnet-Masimbert M (1982) Influence de l'état d'activité des racines sur la floraison induite par des gibbèrellines 4 et 7 chez Pseudotsuga menziesii (Mirb.) Franco. Silvae Genet 31: 178-182

Bonnet-Masimbert M (1987) Preliminary results on gibberellin induction of flowering of seedlings and cuttings of Norway spruce indicate some carry-over effects. Forest Ecol Manage 19: 163-171

Brown JMB (1953) Studies on British beechwoods. Forestry Commission Bulletin 20. HMSO, London

Burley J (1966a) Genetic variation in seedling development of Sitka spruce, Picea sitchensis (Bong.) Carr. Forestry 39: 68-94

Burley J (1966 b) Provenance variation in growth of seedling apices of Sitka spruce. For Sci 12: 170-175

Büsgen M, Münch E, Thompson T (1929) The structure and life of forest trees. Chapman and Hall, London

Caesar JC, Macdonald AD (1984) Shoot development in Betula papyrifera. $\mathrm{V}$. Effect of male inflorescence formulation and flowering on long shoot development. Can J Bot 62: 1708-1713

Chalupka W, Giertych M, Krolikowski Z (1976) The effect of cone crops in Scots pine on tree diameter increment. Arbor Kornickie 21: $361-366$

Chalupka W, Giertych M, Kopcewicz J (1982) Effect of polythene covers, a flower inducing treatment, on the contents of endogenous gibberellin-like substances in grafts of Norway spruce. Physiol Plant 54: $79-82$

Ching TM, Ching KK (1962) Physical and physiological changes in maturing Douglas-fir cones and seed. For Sci 8: $21-31$

Chung M-S (1981) Flowering characteristics of Pinus sylvestris L. with special emphasis on the reproductive adaptation to local temperature factor. Acta For Fenn 169: 1-69

Daubenmire R (1960) A seven-year study of cone production as related to xylem layers and temperature in Pinus ponderosa. Am Midl Nat 64: $187-193$

Debazac EF (1965) Morphogenèse et sexualité chez les Pinacées. Lorraine Sci Bull 5: 212-228

Dickman DI, Kozlowski TT (1969) Seasonal variations in reserve and structural components of Pinus resinosa cones. Am J Bot 56: $515-520$

Ebell LF (1971) Girdling: its effect on carbohydrate status and on reproductive bud and cone development in Douglas-fir. Can J Bot 49: $453-466$

Eis S, Garman EH, Ebell LF (1965) Relation between cone production and diameter increment of Douglas fir [Pseudotsuga menziesii (Mirb.) Franco], grand fir [Abies grandis (Dougl.) Lindl.], and western white pine (Pinus monticola Dougl.). Can J Bot 43: 1553-1559

Eklund B (1954) Variation in the widths of the annual rings in pine and spruce due to climatic conditions in northern Sweden during the years 1900-1944 (in Swedish). Medd Statens Skogsforsknings inst 44: 8, $5-150$

Eklund B (1957) The annual ring variations in spruce in the centre of northern Sweden and their relation to climatic conditions (in Swedish). Medd Statens Skogsforsknings inst 47: 1, 1-53

Enescu V (1987) Climate and the choice of seed orchard sites. Forest Ecol Manage 19: $257-265$

Fielding JM (1960) Branching and flowering characteristics of Monterey pine. Aust For Timber Bur Bull 37

Flückiger W, Braun S, Leonardi S, Förderer L, Bühler U (1989) Untersuchungen an Buchen in festen Waldbeobachtungsflächen des Kantons Zürich. Schweiz Z Forstw 140: 536-550

Fober $\mathrm{H}$ (1976) Relation between climatic factors and Scots pine (Pinus sylvestris L.) cone crops in Poland. Arbor Kornickie 21: 367-374

Fowells HA (compiler) (1965) Silvics of forest trees of the United States. U. S. Department of Agriculture, Washington, Agriculture Handbook No. 271, pp 546-556 
Gross HL (1972) Crown deterioration and reduced growth associated with excessive seed production by birch. Can J Bot 50: 2431-2438

Gross HL, Harden AA (1968) Dieback and abnormal growth of yellow birch induced by heavy fruiting. Information Report $0-X-79$. Sault Sainte Marie, Forest Research Laboratory

Hagem $O$ (1917) Seed crop of pine and spruce in Norway (in Norwegian) Medd Vestl Forstl Forsoeksst 1: 2, 1-188

Harper JL (1977) Population biology of plants. Academic Press, London

Hilton GM, Packham JR (1986) Annual and regional variation on English beech mast (Fagus sylvatica L.). Arbor J 10: 3-14

Holmsgaard E, Olsen HC (1960) The effect of weather in the production of beechnuts. Forstl Forsoegsvaes Dan 26: 347-370

Innes JL (1990) Assessment of tree condition. Forestry Commission Field Book 12. HMSO, London

Innes JL (1992) Observations on the condition of beech (Fagus sylvatica L.) in Britain in 1990. Forestry 65: 35-60

Innes JL (1993 a) Abiotic factors influencing forest condition in the United Kingdom. In: Hüttl RF, Mueller-Dombois D (eds) Forest decline in the Atlantic and Pacific region. Springer, Berlin Heidelberg New York, pp 40-53

Innes JL (1993 b) Forest health: its assessment and status. Commonwealth Agricultural Bureau, Oxford (in press)

Innes JL, Boswell RC (1991) Monitoring of forest condition in the United Kingdom 1990. Forestry Commission Bulletin 98. HMSO, London

Innes JL, Moffat AJ, Lonsdale D (1989) Weather conditions during the summer of 1989 and their effect on trees. Forestry Commission Research Information Note 162. Forestry Commission, Edinburgh

Jackson DI, Sweet GB (1972) Flower initiation in temperate woody plants. Hortic Abstr 42: 9-24

Jonsson A, Ekberg I, Eriksson G (1976) Flowering in a seed orchard of Pinus sylvestris L. Stud For Suec 135: 1-38

Jukola-Sulonen E-L, Mikkola K, Salemaa M (1990) The vitality of conifers in Finland, 1986 - 88. In: Kauppi P, Anttilla P, Kenttämies K (eds) Acidification in Finland. Springer, Berlin Heidelberg New York, pp 523-560

Kessler KJ (1969) Top-dying of yellow birch associated with seed production. Plant Dis Rep 53: 694-697

Köhl M (1989) Number of replications in experimental design. In: Conference on forest statistics, IUFRO 6.02, Freiburg i. Br., $12-15$ September 1989. IUFRO, Freiburg, pp 251-257

Köhl M (1990) Sind "statistisch signifikante" Ergebnisse wirklich signifikant? oder: Gedanken zur Anwendung statistischer Methoden in der forstlichen Forschung. Allg Forst- Jagdz 161: 226-230

Koski V, Tallquist R (1987) Results of long-term measurements of the quality of flowering and seed crop in trees. Folia For 364: 1-60

Kozlowski TT, Keller T (1966) Food relations of woody plants. Bot Rev 32: $293-382$

Krulikowska H, Kopcewicz J, Zatorska Z, Szczesniak T (1978) Auxins and gibberellins in embryonic shoots of Scots pine in relation to flower sex differentiation. Acta Soc Bot Pol 4: 403-409

La Bastide JGA, Van Vredenburch CLH (1970) The influence of weather conditions on the seed production of some forest trees in the Netherlands. Meded Bosbouwproefstation 102: 1-12

Le Tacon F, Osswald H, Bitsch M, Bouchard D, Divoux A (1977) Influence de la fertilization minérale sur la fructification du Hêtre (Fagus sylvatica). Ann Sci For 34: 89-109

Lee KJ (1979) Factors affecting cone initiation in pines: a review. Res Rep Inst For Genet, Suweon, Korea 15: 45-85

Lindgren K, Ekberg I, Eriksson G (1977) External factors influencing female flowering in Picea abies (L.) Karst. Stud For Suec 142: 1 -53

Lindquist B (1931) Biology of the Scandinavian beech forest (in Swedish) Svenska Skogs-Foren Tidskr 3: 179-532

Linnaeus C (1751) Skanska Resa. Stockholm

Löffler J (1988) Gefährden die Immissionen die Fortpflanzung unserer Wälder. Allg Forst Z 43: 916-918

Lüscher D (1989 a) Die Blütenbildung bei Bäumen und ihre Auswirkung auf die Struktur der Krone: II. Die Weisstanne (Abies alba Mill.). Schweiz Z Forstw 140: 239-245
Lüscher D (1989 b) Die Blütenbildung bei Bäumen und ihre Auswirkung auf die Struktur der Krone: III. Die Fichte [Picea abies (L.) Karst]. Schweiz Z Forstw 140: 813-822

Lüscher D (1990) Die Blütenbildung bei Bäumen und ihre Auswirkung auf die Struktur der Krone: IV. Die Buche (Fagus sylvatica L.). Schweiz Z Forstwes 141: 147-154

Lüscher D, Sieber M (1988) Die Blütenbildung bei Bäumen und ihre Auswirkung auf die Struktur der Krone: I. Allgemeines über die Blütenbildung. Schweiz Z Forstw 139: 1055-1061

Maguire WP (1956) Are ponderosa pine crops predictable? J For 54: $778-779$

Matthews JD (1955) The influence of weather on the frequency of beech mast years in England. Forestry 28: 107-116

Melchior GH (1987) Increase of flowering in Norway spruce (Picea abies) by known rootstocks and planting grafts in southern sites. Forest Ecol Manage 19: 23-33

Mikola J (1987) Effects of fertilizer and herbicide application on the growth and cone production of Scots pine seed orchards in Finland. Forest Ecol Manage 19: 183-188

Moir RB and Fox DP (1975) Bud differentiation in Sitka spruce, Picea sitchensis (Bong.) Carr. Silvae Genet 24: 193-196

Morris RF (1951) The effect of flowering on the foliage production and growth of balsam fir. Forestry Chron 27: 40-57

Nemec A (1956) Improving the seeding of Fagus sylvatica by soil improvement (in Czech). Pr Výzk Ustavu CS Naft Dolu 11: 5-25

Nielsen BO (1977) Beech seeds as an ecosystem component. Oikos 29: $268-274$

Nikkanen T, Velling P (1987) Correlations between flowering and some vegetative characteristics of grafts of Pinus sylvestris. Forest Ecol Manage 19: $35-40$

Olsen HC (1978) Induction of flowering in Norway spruce. Det Forstl Forsogsvaes 36: $231-265$

Oppermann A, Bornesbusch $\mathrm{CH}$ (1926) On forests and nurseries (in Danish). Dansk Skovforen Tidss 8. Copenhagen

Owens JN (1987) Development of Douglas-fir apices under natural and cone-inducing conditions. Forest Ecol Manage 19: 85-97

Owens JN, Blake MD (1985) Forest tree seed production. Can For Serv, Petawawa National Forestry Inst, Information report PI-X-53

Owens JN, Molder M (1976) Bud development in Sitka spruce. II. Cone differentiation and early development. Can J Bot 54: 766-779

Owens JN, Molder M (1980) Sexual reproduction of Sitka spruce (Picea sitchensis). Can J Bot 58: 886-901

Owens JN, Singh H (1982) Vegetative bud development and the time and method of cone initiation in subalpine fir (Abies lasiocarpa). Can J Bot 60: 2249-2262

Owens JN, Colangeli AM, Morris SJ (1991) Factors affecting seed set in Douglas-fir (Pseudotsuga menziesii). Can J Bot 69: 229-238

Packham JR, Harding DJL, Hilton GM, Stuttard RA (1992) Functional ecology of woodlands and forests. Chapman and Hall, London

Pharis RP, King RW (1985) Gibberellins and reproductive development in seed plants. Annu Rev Plant Physiol 36: 517-568

Philipson JJ (1983) The role of gibberellin $\mathrm{A}_{47}$, heat and drought in the induction of flowering in Sitka spruce. J Exp Bot 34: 291 -302

Philipson JJ (1985) The promotion of flowering in large field-grown Sitka spruce by girdling and stem injections of gibberellin $\mathrm{A}_{4} / 7$. Can J For Res 15: 166-170

Philipson JJ (1987) Promotion of cone and seed production by gibberellin $A_{4 / 7}$ and distribution of pollen and seed cones on Sitka spruce grafts in a clone bank. Forest Ecol Manage 19: 147-154

Puritch GS (1972) Cone production in conifers: a review of the literature and evaluation of research needs. Pac For Res Cent, Can For Serv Inf Rep BC-X-65

Ross SD (1990) Control of sex expression in potted Picea engelmannii grafts by gibberellin $\mathrm{A}_{4 / 7}$ and the auxin, naphthaleneacetic acid. Can J For Res 20: 875-879

Ross SD, Pharis RP (1987) Control of sex expression in conifers. Plant Growth Regul 6: $37-60$

Ross SD, Webber JE, Pharis RP, Owens JN (1985) Interaction between gibberellin $\mathrm{A}_{4} / 7$ and rootpruning on the reproductive and vegetative process in Douglas-fir. I. Effects on flowering. Can J For Res 15: $341-347$ 
Sarvas R (1957) Studies on the seed setting of Norway spruce. Medd Nor Skogforsoeksves 14: 529-556

Sarvas R (1962) Investigations on the flowering and seed crop of Pinus sylvestris. Comm Inst For Fenn 53: 1-198

Simpson JD, Powell GR (1981) Some factors influencing cone production on young black spruce in New Brunswick. For Chron 57: $267-269$

Smith WH, Stanley RG (1969) Cone distribution in crowns of slash pine (Pinus elliottii Englem.) in relation to stem, crown, and wood increment. Silvae Genet 18: 86-91

Stanley RG (1958) Methods and concepts applied to the study of flowering in pine. In: Thimann KV (ed) The physiology of forest trees. Ronald Press, New York, pp 583-599

Stïtz HP, Frehner E, Burkart A (1987) Nadelverlust der Fichte und Samenqualität. Forstw Cbl 106: 68-77

Tirén L (1935) On cone production in spruce, its periodicity and correlation with temperature and precipitation (in Swedish) Medd Statens Skogsforsksningsinst 28: 413-524

Tompsett PB, Fletcher AM (1977) Increased flowering of Sitka spruce [Picea sitchensis (Bong.) Carr.] in a polythene house. Silvae Genet 26: $84-86$

Tompsett PB, Fletcher AM (1979) Promotion of flowering on mature Picea sitchensis by gibberellin and environmental treatments. The influence of timing and hormonal concentration. Physiol Plant 45: $112-116$
Wachter H (1959) Beobachtungen über des Fruchten von Junglärchen in Vebindung zu vorausgegangenen Spätfrostschäden. Silvae Genet 8: $105-106$

Wachter H (1962) Weitere Beobachtungen zum Blühen und Fruchten von Junglärchen. Silvae Genet 11:153-156

Wareing PF (1958) Reproductive development in Pinus sylvestris. 4. In: Thimann KV (ed) The physiology of forest trees. Ronald Press, New York, pp 643-654

Watt AS (1925) On the ecology of British beechwoods with special reference to their regeneration. II. The development and structure of beech communities on the South Downs. J Ecol 13: 27-73

Webber JE, Ross SD, Pharis RP, Owens JN (1985) Interaction between gibberellin $A 4 / 7$ and rootpruning on the reproductive and vegetative process in Douglas-fir. II. Effects on shoot growth. Can J For Res 15: $348-353$

Wesoly W, Urbanski K, Barzdajn W (1987) Effect of mineral fertilization on flowering of Scots pine (Pinus sylvestris) grafts. Forest Ecol Manage 19: $191-198$

Westman L (1989) A new method for assessment of visible damage to birch and other deciduous trees. In: Bucher JB, Bucher-Wallin I (eds) Air Pollution and forest decline. Eidgenössische Anstalt für das forstliche Versuchswesen, Birmensdorf, pp 223-228

Zasada JC, Sharik TL, Nygren M (1992) The reproductive process in boreal forest trees. In: Shugart HH, Leemans R, Bonan GB (eds) A systems analysis of the global boreal forest. Cambridge University Press, Cambridge, pp 85-125 